\title{
Cezanne enhances epithelial mesenchymal transition and prevents anthracycline-induced apoptosis via AKT/mTOR signaling in hepatocellular carcinoma
}

\section{Xiao-Ping Zhong}

Second Affiliated Hospital of Shantou University Medical College https://orcid.org/0000-0002-0601031X

\section{Jiahong Wang}

Guangzhou Medical College: Guangzhou Medical University

Jie Mei

Sun Yat-Sen University Cancer Prevention and Treatment Center: Sun Yat-sen University Cancer Center Lianghe Lu

Sun Yat-Sen University Cancer Prevention and Treatment Center: Sun Yat-sen University Cancer Center Yihong Ling

Sun Yat-Sen University Cancer Prevention and Treatment Center: Sun Yat-sen University Cancer Center

\section{Shaohua Li}

Sun Yat-Sen University Cancer Prevention and Treatment Center: Sun Yat-sen University Cancer Center

\section{Shijie Tang}

Second Affiliated Hospital of Shantou University Medical College

\section{Anna Kan}

Sun Yat-Sen University Cancer Prevention and Treatment Center: Sun Yat-sen University Cancer Center

\section{Rong-ping Guo ( $\sim$ guorp@sysucc.org.cn )}

Sun Yat-sen University Cancer Center

\section{Research}

Keywords: hepatocellular carcinoma, Cezanne, anthracycline, mTOR signaling pathway, transcatheter arterial chemoembolization, EMT, Rapamycin

Posted Date: July 8th, 2021

DOI: https://doi.org/10.21203/rs.3.rs-676858/v1

License: (c) (1) This work is licensed under a Creative Commons Attribution 4.0 International License. Read Full License 
Page $2 / 30$ 


\section{Abstract \\ Background}

Anthracycline resistance have hindered the efficacy of transcatheter arterial chemoembolization (TACE).

Translational research is therefore in need to find potential combinations by studying the resistance mechanism of anthracycline. In our published work, we found Cezanne could predict the efficacy of adjuvant TACE (ad-TACE) and induce epithelium mesenchymal transition (EMT) in hepatocellular carcinoma (HCC). We hereby conduct a sequential investigation to reveal the role of Cezanne on EMT and its potential to retard resistance.

\section{Methods}

The response of Cezanne in patients treated with adjuvant TACE after hepatectomy was evaluated. Functional assays were used to examine the resistance function of Cezanne to anthracyclin. In-situ tumorigenesis models and intraperitoneal perfusion chemotherapy experiment were used for in vivo verification.

\section{Results}

High expression of Cezanne correlated to a better outcome. Multivariate analysis showed low expression of Cezanne and the application of postoperative ad-TACE therapy were independent prognostic risk factors. However, patient outcome was significantly shorter in high Cezanne group of ad-TACE patients. In vitro assays revealed that HCC functions were inhibited after overexpressing Cezanne (OE-Cezanne). After treated with epirubicin, however, OE-Cezanne cell lines did not respond to treatment. In vivo experiment was consistent with in vitro assays. Besides, high Cezanne transforms cell morphology and is correlated to the activation of EMT related genes. Gene set analysis showed that Cezanne can regulate $\mathrm{PISK} / \mathrm{AKT} / \mathrm{mTOR}$ signaling pathway. Therefore, mTOR inhibitor Rapamycin can reverse the resisting effect of Cezanne on HCC cell lines.

\section{Conclusions}

Adjuvant anthracycline-based TACE treatment after curative surgery can reduce the recurrence rate in HCC patients. However, in patients with high Cezanne expression, the efficacy of TACE may be undermined by EMT inducement. We discovered Cezanne modulates EMT by activating the AKT/mTOR signaling pathway and provided evidence for the rationale of combining mTOR inhibitor with TACE to prevent recurrence in $\mathrm{HCC}$ patients.

\section{Background}


Tumor recurrence complicates $70 \%$ cases of hepatocellular carcinoma (HCC) at five years after curative resection ${ }^{1,2,3}$. In the 2018 EASL Clinical Practice Guidelines, however, the panel did not recommend adjuvant therapy after liver resection but strongly encouraged the development of prospective studies as evidence were insufficient ${ }^{1}$. In our previous study, we therefore conducted an investigation on the most widely used postoperative adjuvant treatment, transcatheter arterial chemoembolization (TACE), and its efficacy on delaying tumor recurrence and prolonging the survival of HCC patients ${ }^{4}$. We concluded that hepatectomy followed by adjuvant TACE can significantly increase the 2-year disease free rate by approximately $20 \%{ }^{4}$. In spite of the evident reduction of recurrence, these results also suggested that around $40 \%$ of patients did not respond to adjuvant TACE.

Anthracycline-based TACE is an irreplaceable regimen for HCC treatment ${ }^{5,6,7}$. Anthracycline resistance, nonetheless, have been an ongoing poser since its discovery in the $1960 \mathrm{~s}^{8}$. Progress have been made in understanding the regulatory mechanism of anthracycline resistance 9,10 and finding combinations to enhance the efficacy of TACE ${ }^{11,12}$. Surprisingly, translational research in discovering potential combinations by studying the resistance mechanism of anthracycline are rare. In our published work, we found that the deubiquitinating enzyme Cezanne could predict the efficacy of adjuvant TACE and induce epithelium to mesenchymal transition (EMT) in HCC cell lines ${ }^{13}$, while the mechanism remains unknown.

We hereby conduct a sequential investigation to reveal the role of Cezanne on EMT. In this study, we discovered the regulatory mechanism of Cezanne by analyzation of three independent cohorts. In vivo and in vitro experiments were conducted for verification of the results from bioinformatic gene enrichment and pathway analysis. Finally, we found that mammalian target of rapamycin (mTOR) inhibitor could enhance anthracycline sensitivity and perhaps retard resistance. This study gives rationale to postoperative adjuvant TACE by elucidating a novel mechanism of anthracycline resistance. Our results also led to a potential translational target that may further consolidate the potency of TACE and give rationale to the clinical application of TACE combined with mTOR inhibitor to benefit more HCC patients.

\section{Materials And Methods}

HCC cohorts and transcriptomic data sets. A total of three cohorts were used in this study. Cohort 1 included 1064 HCC patients from The Cancer Genome Atlas (TCGA) database. Cohort 2 consisted of 147 HCC patients treated with TACE, all patients had available mRNA transcriptome data (GSE104580). Cohort 3 is a microarray cohort consisted of $537 \mathrm{HCC}$ patients with available archived formalin-fixed paraffin-embedded HCC tissues collected between January 2007 to December 2013 in Sun Yat-sen University Cancer Center (SYSUCC). This study was approved by the institutional review board and human ethics committee of SYSUCC. Written consent for using samples for research purposes was obtained from all patients before surgery. Patients included in this study had complete medical records and met the following criteria: (1) resectable liver cancer that was pathological diagnosed HCC, (2) no diagnosed distant metastasis, (3) no anticancer therapies before surgery. Patients with other 
complications or malignant were excluded. Tumor stage was classified according to The Barcelona-Clinic Liver Cancer (BCLC) staging system. Overall survival (OS) was defined as the date of liver resection to the date of death or last follow-up. Disease-free survival (DFS) was measured from the date of surgery until the date of relapse, metastasis or last follow-up.

Transcatheter arterial chemoembolization. Patients comes back for a return visit 1-2 months postsurgery. Hepatic arterial angiography was first taken, and preventive chemoembolization was performed if tumor stain was not observed in the remaining liver. The regimen was given as previously reported ${ }^{13}$.

Follow-up. Follow-ups consisted of physical examination, tumor marker measurement, liver biochemistry and function, blood tests, abdominal ultrasonography, and contrast- enhanced CT and were conducted for all patients less than every 1-3 months for the first year after liver operations and every 6 months thereafter for more than 60 months after treatment. The last follow-up was October 2020. The overall survival (OS) time was defined as the interval between surgery and death or between surgery and the last follow-up for surviving patients. The recurrence-free survival time was defined as the interval between surgery and recurrence or between surgery and the last follow-up for patients without recurrence. The diagnosis of recurrence was confirmed by serum a-fetoprotein (AFP) level, abdominal ultrasonography every 2 months and CT or magnetic resonance imaging or positron emission tomography every 6 months.

Tissue microarray (TMA) construction, IHC staining and scoring system. This cohort consisted of 537 HCC paired samples. Formalin-fixed, paraffin-embedded tissues (by hepatectomy of the HCC tumor and adjacent tissue) used in this study were from the archive of the Department of Pathology, SYSUCC. The IHC staining method was as previously reported ${ }^{13}$. The sections were incubated with the Cezanne mouse clonal antibody (working dilution 1: 200, Abcam, Cambridge, UK, ab118387). Automated image acquisition was captured by the Vectra slide scanner. A scanning protocol was created based on the TMA core number and size. Nuance multispectral image cubes were further acquired and used to build the spectral libraries. The pattern recognition-based image analysis of the InForm 1.2 software package was used to segment tissue and subcellular compartments. Then, the target signals were quantitated within the selected tissue and subcellular compartment(s) of interest. The detailed protocol was as previously reported ${ }^{14}$.

Cell culture. Two human HCC cell lines were used in this study: SK-Hep1 and SMCC-7721. The two cell lines were obtained from the Liver Cancer Institute of Fudan University (Shanghai, China) and maintained in Dulbecco's modified Eagle's medium (DMEM, Gibco, Carlsbad, CA, USA) supplemented with 10\% fetal bovine serum (Gibco) at $37^{\circ} \mathrm{C}$ under $5 \% \mathrm{CO} 2$. The optimal concentration of epirubicin and Rapamycin for cell culture was examined by CCK-8 assay (Fig. S1).

Plasmid constructs and transfection. Full-length human Cezanne cDNA was amplified by PCR and cloned into pcDNA3.1(+) expression vector (Invitrogen, Carlsbad, CA, USA), and then transfected into SK-Hep1 and SMMC-7721 cell using Lipofectamine 2000 (Invitrogen) according to the manufacturer's instructions. 
Cell transfected with empty vector were used as controls. Stable Cezanne-expressing clones were selected by Geneticin (Rache Diagnostics, Indianapolis, IN, USA) at the concentration of $500 \mu \mathrm{g} / \mathrm{ml}$.

Total RNA extraction and RT-qPCR. Total RNA was extracted from HCC cell lines using TRIzol reagent (Invitrogen) according to the manufacturer's protocol. The total RNA $(2 \mu \mathrm{g})$ was reverse transcribed using a PrimeScript RT Kit (Takara, Dalian, China) for first-strand cDNA synthesis. The primer sequences used are listed in table S1. The cDNA was subjected to quantitative real-time PCR (RT-qPCR) using the SYBR Green PCR Kit (Applied Biosystems, Carlsbad, CA, USA), and the assay was performed to the manufacturer's protocol.

Western blotting. Western blot analyses were performed according to the standard protocol.

CCK-8 assay. Cells were cultured in 96-well plates, 2000 cells were planted in each well and cultured for $24,48,72,96$ or $120 \mathrm{~h}$. Once the incubation with CCK-8 (Zomanbio, Beijing, China) had been carried out for $2 \mathrm{~h}$, the corresponding optical density (OD) values were detected at $450 \mathrm{~nm}$.

Wound healing assay. $\mathrm{HCC}$ cell lines were seeded in 6 -well plates at $2 \times 10^{6}$ cells $/ \mathrm{mL}$ and incubated for 24-48 h. After cells reached $100 \%$ confluence, wounds were generated using a $1 \mathrm{~mL}$ micropipette tip. Media was removed, cells washed with $500 \mu \mathrm{L}$ PBS, and $500 \mu \mathrm{L}$ of complete culture media containing compounds added into each well. Images were acquired immediately following media replacement, and every $6 \mathrm{~h}$ for $24 \mathrm{~h}$. After exporting images, wound areas were measured. The detailed protocol was provided by Paster et al. ${ }^{15}$.

Cloning assay. This assay was done according to the protocol provided by Franken et al. ${ }^{16}$.

Transwell migration and invasion assay. We performed this experiment according to the protocol provided by Pijuan et al. ${ }^{17}$

Annexin V staining protocol for apoptosis. $5 \times 10^{5}$ cells were collected in each group and analyzed by flow cytometry according to the manufacturer's protocol.

Cell cycle analysis. $5 \times 10^{4}$ cells were collected in each group and dyed with propidium iodide and analyzed by flow cytometry according to the manufacturer's protocol.

In vivotumorigenesis assay and intraperitoneal perfusion chemotherapy experiment. All the animal experiments were performed in accordance with the guidelines of the Laboratory Animal Ethics Committee of Sun Yat-Sen University. For the in vivo in-situ tumorigenesis model, $5 \times 10^{6}$ cells were injected intrahepatic into BALB/C-nu/nuathymic nude mice. Briefly, the mice were anesthetized and a midline incision was made to expose the liver. HCC cell lines were resuspended in matrigel (1:1) and slowly injected under the hepatic capsule into the liver. After three weeks, the mice were divided into four groups (OE, OE + epirubicin, vec, vec + epirubicin) with four mice in each group. Three days after the end of perfusion, the mice were sacrificed. The tumor and adjacent tissue were collected. The tumor was 
photographed, and the diameter and weight of the tumor were measured. Partial samples were stored in the $-80^{\circ} \mathrm{C}$. A portion of samples were fixed in formalin, fixed in phosphate-buffered neutral formalin, sectioned serially, and stained with hematoxylin-eosin. Then, immunohistochemical analysis was performed.

Bioinformatic analysis. Cezanne expression in normal and cancer tissues was assessed by the Human Protein Atlas (HPA) (http://www.proteinatlas.org/). The relationships between the altered level of Cezanne and the OS or DFS of cancer patients were analyzed using cBioPortal (https://www.cbioportal.org/) and the log-rank test, with Cox proportional hazard ratio (HR) and 95\% confidence intervals calculated. Gene Expression Profiling Interactive Analysis (GEPIA) profiling plotting and correlation analysis based on the RNA-Seq expression data from The Cancer Genome Atlas (TCGA). It was used to compare Cezanne expression between cancer and normal tissues. Furthermore, we explored the correlation between gene expression through GEPIA, and gene expression correlation analysis was performed for the given TCGA datasets in GEPIA, with the Spearman method being used. Hierarchical cluster analysis (HCA) was used to reveal natural cluster within the data.

Propensity score matching (PSM) analysis. The 537 HCC patients recruited in cohort 3 was analyzed retrospectively. Treatment regimens were therefore not assigned randomly and may lead to potential for confounding and selection biases between groups that could impact the comparisons of outcomes. Accordingly, PSM was conducted to overcome the biases produced by disequilibrium between the two groups. The propensity score was calculated by the logistical regression model using the baseline clinical characteristics as covariates. PSM was performed as one-to-two matching between the AR and NAR groups with nearest neighbor matching and a 0.1 caliper width using SPSS (IBM SPSS Statistics for Windows, version 19.0. IBM Corp., Armonk, NY) and Propensity Score Matching for SPSS, version 1.0 (Felix Thoemmes, Cornell University/University of Tübingen).

Statistical analysis. For continuous variables, the data are expressed as the mean \pm standard error of the mean. The significance of differences between values was determined using the Student $t$ test. The chisquared test was applied to examine the correlation between Cezanne expression and clinical pathological parameters. Survival curves for patients were calculated using the Kaplan-Meier method and analyzed using the log-rank test. Prognostic factors were examined by univariate and multivariate analyses using the Cox proportional hazards model. All differences were deemed significant at $\mathrm{P}<0.05$. All statistical analyses were performed with SPSS software version 25.0 (SPSS, Chicago, IL).

\section{Results}

\section{Aberrant Cezanne expression predicts worse outcome and better response to adjuvant TACE therapy in HCC patients}

The aberrant regulation of Cezanne was observed in several tumor types, with a significantly higher expression in tumor tissues, including HCC (Fig. 1A). In cohort 1, the alteration of Cezanne was detected 
in 1064 HCC patients. Our analysis suggested a better OS $(P=0.0191)$ and disease-free survival (DFS, $P$ $=0.0811)$ in patients with unaltered Cezanne expression (Fig. 1B, 1C).

We collected 537 HCC patient samples in cohort 3. In our previous report, we found that liver cirrhosis was a significant clinical parameter in the low Cezanne-expressed patients ${ }^{13}$. In this study, we expanded our sample population and the result was in accordance with our earlier finding (Table. S2). After PSM, the overall baseline characteristics were even between patients that received adjuvant TACE therapy after curative treatment (ad-TACE group) and those who didn't (surgery group) (Table 1). In the end, 418 patients were included into this study, with 270 patients in the ad-TACE group. The clinicopathological features is listed in Table S3. 
Table 1

Correlation of adjuvant TACE with clinic-pathological parameters after PSM

\section{Characteristics}

Adjuvant TACE

Yes $(n=270)$

\section{Epidemiology}

Age (year)

Gender

Male

Female

Etiology

Virus(HBV/HCV)

Positive

Negative

Liver function

PT

$\operatorname{PLT}\left(* 10^{9} / \mathrm{L}\right)$

ALB (g/L)

TBIL (umol/L)

Cirrhosis

Yes

No

Child-Pugh Class

A

$B \& C$

Tumor burden

BCLC stage

A
B
C

$46.9 \pm 11.3$

239(88.5)

31(11.5)
264(97.8)

$6(2.2)$
211(78.1)

46(17.0)

13(4.9)

No $(n=148)$

P-value

0.090

0.674

133(89.9)

15(10.1)

0.423

130(87.8)

18(12.2)

15(5.5)

$12.7 \pm 1.4$

0.217

$12.4 \pm 1.3$

$193.0 \pm 88.8$

0.867

$190.4 \pm 63.5$

$43.1 \pm 3.9$

0.144

$41.9 \pm 4.2$

$14.9 \pm 5.6$

$15.0 \pm 5.1$

0.947

0.588

99(66.9)

49(33.1)

64(23.7)

0.955

145(98.0)

3(2.0)

0.027

139(93.9)

6(4.1)

3(2.0) 


\begin{tabular}{|c|c|c|c|}
\hline \multirow[t]{2}{*}{ Characteristics } & \multicolumn{2}{|l|}{ Adjuvant TACE } & \multirow[t]{2}{*}{ P-value } \\
\hline & Yes $(n=270)$ & No $(n=148)$ & \\
\hline $\mathrm{AFP}(\mathrm{ng} / \mathrm{ml})$ & $10392.7 \pm 28053.3$ & $15703.2 \pm 36557.3$ & 0.408 \\
\hline GGT (U/I) & $95.0 \pm 77.7$ & $65.3 \pm 60.8$ & 0.034 \\
\hline \multicolumn{3}{|l|}{ Tumor capsule } & 0.779 \\
\hline Complete & $69(25.6)$ & $56(37.8)$ & \\
\hline No/incomplete & $201(74.4)$ & $92(62.2)$ & \\
\hline \multicolumn{3}{|l|}{ Tumor differentiation } & 0.125 \\
\hline I & $15(5.6)$ & $22(14.9)$ & \\
\hline ॥ & $245(90.7)$ & $115(77.7)$ & \\
\hline III & $10(3.7)$ & $11(7.4)$ & \\
\hline \multicolumn{3}{|l|}{ Vascular invasion } & 0.056 \\
\hline Yes & $65(24.2)$ & $21(14.2)$ & \\
\hline No & $205(75.8)$ & $127(85.8)$ & \\
\hline \multicolumn{3}{|l|}{ Tumor number } & 0.021 \\
\hline Single & $133(49.4)$ & $123(83.1)$ & \\
\hline Multiple & $135(50.6)$ & $25(16.9)$ & \\
\hline Tumor size $(\mathrm{cm})$ & $7.6 \pm 3.9$ & $7.2 \pm 3.8$ & 0.071 \\
\hline \multicolumn{4}{|l|}{$\mathrm{IHC}$} \\
\hline \multicolumn{3}{|l|}{ Cezanne expression } & 0.435 \\
\hline High & 133(49.3) & $67(45.3)$ & \\
\hline Low & $137(50.7)$ & $81(54.7)$ & \\
\hline \multicolumn{3}{|l|}{ Recurrence status } & 0.000 \\
\hline Yes & $230(92.7)$ & $91(78.9)$ & \\
\hline No & $18(7.3)$ & $26(21.1)$ & \\
\hline \multicolumn{4}{|c|}{ Values are expressed as the mean \pm SD or no. (\%), unless otherwise indicated; } \\
\hline \multicolumn{4}{|c|}{$\begin{array}{l}\text { PSM, propensity score matching; HBV, hepatitis B virus; HCV, hepatitis C virus; PT, prothrombin time; } \\
\text { PLT, platelet count; ALB albumin; TBIL, total bilirubin; AFP, alpha-fetoprotein. GGT, gamma- } \\
\text { glutamyltransferase; TACE, trans-catheter arterial chemoembolization; IHC, immunohistochemistry; }\end{array}$} \\
\hline
\end{tabular}


The expression of Cezanne was examined (Fig. 1D). According to the IHC score, the area under the curve was calculated by ROC curve and Youden index was calculated (Youden index = sensitivity + specificity 1). The score corresponding to the highest value of Youden index was taken as the cut-off point. Cezanne expression was classified as high expression if the score was higher than the cut-off point, if the score was less than or equal to the cut-off point, the case was classified as low expression, generated by InForm 1.2 software package (Fig. 1E). In the ad-TACE group, Cezanne were highly expressed in 133 patients $(66.5 \%)$ and low in the other 137 patients. The OS and DFS were significantly shorter in the adTACE high expression group $(P<0.001$, Fig. $1 F, 1 H)$. In patients with high expression of Cezanne, the adTACE group showed worse outcome (Fig. 1G, 1I). Single factor analysis of clinicopathological indicated that other than preoperative serum glutamyl transpeptidase, serum platelet count, tumor diameter, tumor capsule and vascular invasion, the high expression of Cezanne and the application of adjuvant TACE could also impact the OS $(P<0.001, P=0.008)$ and DFS $(P=0.001, P<0.001)$ (Table 2). Multivariate analysis with Cox regression model further verified that low expression of Cezanne and the application of postoperative adjuvant TACE therapy were independent prognostic risk factors for $O S(P<0.001 ; P=$ $0.018)$ and DFS $(P=0.001 ; P<0.001)$ (Table. 2$)$. 
Table 2

Univariate analysis and multivariate analysis of overall survival and disease-free survival for patients after PSM.

\begin{tabular}{|c|c|c|c|c|c|c|c|c|}
\hline \multirow[t]{3}{*}{ Variables } & \multicolumn{4}{|l|}{ OS } & \multicolumn{4}{|l|}{ DFS } \\
\hline & \multirow{2}{*}{$\begin{array}{l}\begin{array}{l}\text { Univariate } \\
\text { analysis }\end{array} \\
\text { P-value }\end{array}$} & \multicolumn{3}{|c|}{ Multivariate analysis } & \multirow{2}{*}{$\begin{array}{l}\text { Univariate } \\
\text { analysis }\end{array}$} & \multicolumn{3}{|c|}{ Multivariate analysis } \\
\hline & & HR & $95 \% \mathrm{Cl}$ & $\begin{array}{l}\mathrm{P}- \\
\text { value }\end{array}$ & & HR & $95 \% \mathrm{Cl}$ & $\begin{array}{l}\mathrm{P}- \\
\text { value }\end{array}$ \\
\hline $\begin{array}{l}\text { Age ( } \leq 50 \text { vs. } \\
\bigotimes 50) \text { (year) }\end{array}$ & NS & & & & NS & & & \\
\hline $\begin{array}{l}\text { Gender (male vs. } \\
\text { female) }\end{array}$ & NS & & & & NS & & & \\
\hline $\begin{array}{l}\text { Virus (positive } \\
\text { vs. negative) }\end{array}$ & NS & & & & NS & & & \\
\hline $\begin{array}{l}\mathrm{PT}(\leq 13.5 \mathrm{vs} \\
\text { ه13.5) (sec) }\end{array}$ & NS & & & & NS & & & \\
\hline $\begin{array}{l}\mathrm{PLT}(\leq 100 \text { vs. } \\
\otimes 100)\left({ }^{*} 10^{9} / \mathrm{L}\right)\end{array}$ & 0.020 & & & & NS & & & \\
\hline $\begin{array}{l}\text { ALB }(\leq 35 \text { vs. } \\
\llbracket 35)(\mathrm{g} / \mathrm{L})\end{array}$ & NS & & & & NS & & & \\
\hline $\begin{array}{l}\text { TBIL ( } \leq 17.5 \text { vs. } \\
\text { ه17.5) (umol/L) }\end{array}$ & NS & & & & NS & & & \\
\hline $\begin{array}{l}\text { Cirrhosis (yes vs. } \\
\text { no) }\end{array}$ & NS & & & & NS & & & \\
\hline $\begin{array}{l}\text { AFP }(\leq 400 \mathrm{vs} . \\
\square 400)(\mathrm{ng} / \mathrm{ml})\end{array}$ & NS & & & & NS & & & \\
\hline $\begin{array}{l}\mathrm{GGT}(\leq 50 \text { vs. } \\
\text { ه50) }(\mathrm{U} / \mathrm{I})\end{array}$ & 0.023 & & & & 0.049 & & & \\
\hline $\begin{array}{l}\text { Tumor number } \\
\text { (single/multiple) }\end{array}$ & NS & & & & NS & & & \\
\hline $\begin{array}{l}\text { Tumor size }(\leq 5 \\
\text { vs. } \varangle 5)(\mathrm{cm})\end{array}$ & 0.000 & 3.171 & $\begin{array}{l}1.515- \\
6.640\end{array}$ & 0.002 & 0.001 & 1.387 & $\begin{array}{l}1.099- \\
1.751\end{array}$ & 0.006 \\
\hline $\begin{array}{l}\text { Tumor size }(\leq 5 \\
\text { vs. } \varangle 5)(\mathrm{cm})\end{array}$ & 0.000 & 3.116 & $\begin{array}{l}1.736- \\
5.594\end{array}$ & 0.000 & 0.000 & 1.858 & $\begin{array}{l}1.158- \\
2.983\end{array}$ & 0.010 \\
\hline $\begin{array}{l}\text { Tumor capsule } \\
\text { (Complete vs. } \\
\text { No/incomplete) }\end{array}$ & 0.008 & 0.402 & $\begin{array}{l}0.188- \\
0.859\end{array}$ & 0.019 & 0.027 & 0.458 & $\begin{array}{l}0.235- \\
0.893\end{array}$ & 0.022 \\
\hline $\begin{array}{l}\text { Tumor } \\
\text { differentiation (I- } \\
\text { II vs. III-IV) }\end{array}$ & NS & & & & NS & & & \\
\hline
\end{tabular}




\begin{tabular}{|c|c|c|c|c|c|c|c|c|}
\hline \multirow[t]{3}{*}{ Variables } & \multicolumn{4}{|l|}{ os } & \multicolumn{4}{|l|}{ DFS } \\
\hline & \multirow{2}{*}{$\begin{array}{l}\text { Univariate } \\
\text { analysis } \\
\text { P-value }\end{array}$} & \multicolumn{3}{|c|}{ Multivariate analysis } & \multirow{2}{*}{$\begin{array}{l}\text { Univariate } \\
\text { analysis } \\
\text { P-value }\end{array}$} & \multicolumn{3}{|c|}{ Multivariate analysis } \\
\hline & & HR & $95 \% \mathrm{Cl}$ & $\begin{array}{l}\mathrm{P}- \\
\text { value }\end{array}$ & & HR & $95 \% \mathrm{Cl}$ & $\begin{array}{l}\mathrm{P} \text { - } \\
\text { value }\end{array}$ \\
\hline $\begin{array}{l}\text { Vascular } \\
\text { invasion (Yes vs. } \\
\text { No) }\end{array}$ & \multicolumn{4}{|l|}{0.035} & \multicolumn{4}{|l|}{ NS } \\
\hline $\begin{array}{l}\text { Cezanne } \\
\text { expression (High } \\
\text { vs. Low) }\end{array}$ & 0.000 & 0.709 & $\begin{array}{l}0.544- \\
0.851\end{array}$ & 0.000 & 0.001 & 0.675 & $\begin{array}{l}0.540- \\
0.845\end{array}$ & 0.001 \\
\hline $\begin{array}{l}\text { Adjuvant TACE } \\
\text { (Yes vs. No) }\end{array}$ & 0.008 & 2.216 & $\begin{array}{l}1.146- \\
4.283\end{array}$ & 0.018 & 0.000 & 2.095 & $\begin{array}{l}1.644- \\
2.670\end{array}$ & 0.000 \\
\hline \multicolumn{9}{|c|}{$\begin{array}{l}\text { TNM stage, ALBI stage, BCLC stage and Milan criteria were combined with several clinical indexes } \\
\text { such as tumor number, size TBIL and tumor thrombus; we didn't put TNM stage, ALBI stage, BCLC } \\
\text { stage and Milan criteria into multiple analysis to avoid any bias in analysis. }\end{array}$} \\
\hline \multicolumn{9}{|c|}{$\begin{array}{l}\text { OS, overall survival; DFS, disease-free survival; PSM, propensity score matching; HR, hazard ratio; CI, } \\
\text { confidence interval; AR, anatomical resection; NAR, non-anatomical resection; PT, prothrombin time; } \\
\text { PLT, platelet count; ALB, albumin; AST, aspartate aminotransferase; TBIL, total bilirubin; AFP, alpha- } \\
\text { fetoprotein; GGT, gamma-glutamyltransferase; TACE, trans-catheter arterial chemoembolization; NS } \\
\text { not significant; }\end{array}$} \\
\hline
\end{tabular}

\section{Cezanne affects epirubicin efficacy in both in vivo and in vitro experiments}

We used epirubicin in our experiments as it was the most commonly used anthramycin in TACE $18,19,20$. Wound healing assay (Fig. 2A, 2B), cloning assay (Fig. 2C, 2D), transwell migration and invasion assay (Fig. 2E, 2F) and CCK-8 assay (Fig. 2G, 2H) results all indicated that proliferation, migration and invasion functions were inhibited after overexpressing Cezanne in HCC cell lines (OE-Cezanne) compared to vector cell lines. After treating the cell lines with epirubicin, however, OE-Cezanne cell lines did not respond well to treatment compared to vector cells lines.

In vivo experiment was consistent with in vitro assays. Results from in-situ tumorigenesis in nude mice showed that tumors in the OE-Cezanne group grew slower in both diameter and weight compared to control group (Fig. 2l). Three weeks after the in-situ tumors were formed, the mice were treated with intraperitoneal $0.2 \mathrm{mg} / \mathrm{ml} / \mathrm{mouse} /$ time epirubicin once every two days. The control group were given equal volume and frequency of saline. The results showed that after two weeks of intraperitoneal epirubicin treatment, tumors in the OE-Cezanne group grew faster than the control group in both diameter and weight ( $0.43 \pm 0.093$ vs. $0.26 \pm 0.12 \mathrm{~cm}, \mathrm{P} \otimes 0.05 ; 1.09 \pm 0.13$ vs. $0.72 \pm 0.29 \mathrm{~g} \square \mathrm{P} \otimes 0.05)$ (Fig. 2l). Abdominal and lung metastasis were also more apparent in OE-Cezanne group (62.5\% vs. 25\%). related genes 
In our previous report, we found that the expression of Cezanne in HCC cell lines and patient samples were positively correlated with the expression of EMT markers E-cadherin and vimentin (4). We therefore used GEPIA gene correlation analysis in search of gene regulation correlated to Cezanne. The results showed that epithelial markers (Fig. 3A) such as COL4A1 $\left(P<10^{-14} ; \mathrm{r}=0.32\right)$ and E-cadherin $(P<0.005 ; \mathrm{r}$ $=0.15)$, mesenchymal markers (Fig. 3B) including vimentin $(P<0.005 ; r=0.12)$, slug $(P<0.001 ; r=0.16)$, and $\mathrm{N}$-cadherin $(P<0.001 ; r=0.43)$ and other regulating markers of EMT (Fig. $3 \mathrm{C}$ ) were significantly correlated with Cezanne. In vitro experiments of HCC cell lines also showed that after Cezanne was over expressed, we observed morphology transformations in the cells. Cezanne over expression cells were elongated and displayed spindle-like morphologies compared to vector cells (Fig. 3D). Cezanne's correlation with EMT was also analyzed and observed in multiple cancer types, including colon adenocarcinoma, head and neck squamous cell carcinoma, prostate adenocarcinoma and stomach adenocarcinoma (Fig. 3E).

\section{Cezanne activates EMT by regulating PI3K/AKT/mTOR signaling pathway}

Expression profiling array of cohort 2 was used for gene correlation analysis to investigate the regulating mechanism of Cezanne. Genes with significant difference were visualized as a volcano plot (Fig. 4A). Gene set pathway enrichment analysis indicated that up-regulation of Cezanne was highly correlated with mitotic cell cycle progression (Fig. 4B). HCA of the significantly different genes revealed 2 main clusters of co-regulated genes (Fig. 4C). The genes were regulator genes of the PI3K/AKT/mTOR signaling pathway.

In vitro experiments were done to examine the results of bioinformatic analysis. Western blotting and qPCR analysis showed that regulating factors in the PI3K/AKT/mTOR signaling pathway, AKT1 and mTOR had a higher expression in the Cezanne overexpression cell lines compared to the control group. This difference was even more significant after treating HCC cell lines with epirubicin (Fig. 4D, 4E). Tumor tissue from the nude mice in situ tumorigenesis model was also examined, and the results also showed higher expression of AKT1 and mTOR in the Cezanne overexpression group (Fig. 4F).

\section{mTOR inhibitor Rapamycin can reverse the resisting effect of Cezanne on HCC cell lines}

We applied mTOR inhibitor Rapamycin in functional assays. After stimulating HCC cell lines with Rapamycin, wound healing assay (Fig. 5A), cloning assay (Fig. 5B), CCK-8 assay (Fig. 5C, 5D), transwell migration and invasion assay (Fig. 5E), apoptosis assay (Fig. 5F) results all indicated that proliferation, migration and invasion functions showed significant difference in OE-Cezanne cell lines treated with epirubucin compared with OE-Cezanne cell lines without epirubucin. After stimulated with Rapamycin, OECezanne cell lines responded better to epirubicin compared to OE-Cezanne cell lines without Rapamycin. Furthermore, cell cycle analyzation assay indicated that OE-Cezanne cell lines treated with Rapamycin were significantly arrested in $\mathrm{G} 1$ phase (Fig. $5 \mathrm{G}$ ). 
We detected the expression of Cezanne, mTOR and AKT1 in OE-Cezanne cell lines treated with epirubicin by Western blot (Fig. 5H). The expression of mTOR and AKT1 decreased with Rapamycin, while the expression of Cezanne remained unchanged. This result was confirmed by mRNA expression detected with RT qPCR (Fig. 5I).

\section{Discussion}

mTOR pathway regulators, including pRPS6, p-AKT, IGF-1R and RICTOR are up-regulated in 40-50\% of HCCs 21,22 . Activation of the mTOR pathway in HCC is associated with less differentiated tumors, bad prognosis, and earlier recurrence ${ }^{22}$. In transgenic mice, mTOR activation by itself was shown to be sufficient for HCC development ${ }^{23}$. mTOR pathway inhibitors, on the other hand, are routine immunosuppressors for the prevention of graft rejection after transplantation ${ }^{24}$. It may also reduce liver fibrosis ${ }^{25}$ and have additional antitumor function. Results of a meta-analysis of 5 studies including nearly 3000 HCC patients indicated that survival were significantly prolonged after liver transplantation with the administer of mTOR inhibitor sirolimus (Rapamycin) ${ }^{26}$. mTOR inhibitors also showed potential as adjuvant therapy in HCC patients after liver transplantation and TACE ${ }^{21}$. Currently, several ongoing clinical trials are hopeful that mTOR inhibitor being an effectual combination for HCC treatment. The rationale of the mechanism, however, remains implicit.

Cezanne is known as a deubiquitinase that plays a role in inflammation and proliferation signaling processes by modulating protein stability 27, 28, 29, 30,31. Previous studies have shown that Cezanne deubiquitinase removes polyubiquitin chains from mTOR assemble factor G $\beta$ L to promote G $\beta L$ interaction with mTOR component SIN1, facilitating mTORC2 formation in response to various growth signals ${ }^{27}$. In our published work, we found that besides Cezanne pivotal role in tumor progression and prognosis, it also contributes to the selection of patients who may benefit from adjuvant TACE to prevent recurrence ${ }^{13,32}$. Sequentially, we conducted this study to validate the value of adjuvant TACE on preventing recurrence in HCC and its mechanism. From our results calculated by PSM analysis, we suggest that tumors diameter larger than $5 \mathrm{~cm}$, tumors with infiltrating growth, or tumors with low Cezanne expression are indications of adjuvant TACE therapy. We also discovered that high expression of Cezanne can reduce tumor response to TACE. The potential of Cezanne as a molecular target to improve TACE efficacy was further researched.

After analyzing three datasets including 1748 HCC patients, we found that the expression of Cezanne positively correlated with EMT regulator genes. During EMT, a new transcriptional program is activated to promote the mesenchymal fate ${ }^{33}$. Cells with different molecular characteristics within the same tumor respond differently to anti-cancer therapeutics, leading to drug resistance $33,34,35$. Pathologically, EMT manifests as fibrosis ${ }^{36}$. In our initial clinical investigation, statical analyzation indicated aberrant expression of Cezanne correlated with liver cirrhosis. This result was supported by dynamic cell plasticity after overexpression of Cezanne in HCC cell lines. Besides, after overexpressing Cezanne, in vivo and in vitro HCC models were insensitive to anthrocyclin treatment. In other words, anthracyclines effect may be 
enhanced by blocking Cezanne-activated EMT. Gene enrichment analysis of patient transcriptome sequencings and sequencing of two anthracycline-resistance HCC cell lines all support that Cezanne regulated the AKT/mTOR pathway. Our research also showed that mTOR inhibitor Rapamycin could increase OE-Cezanne cell lines sensitivity to anthrocyclins by reversing EMT (Fig. 6).

Finding strategies to reduce tumor recurrence is a pressing matter. Combination therapy are agreed as a promising regimen to reduce resistance and Several phase III trials have been reported with TACE as standard of care, but none of these trials has provided convincing evidence of clinically meaningful benefit over TACE alone $37,38,39,40$. Although the rationale for these combinations seemed sound, however, most lack the support of transcriptomic research. We hereby provide evidence mTOR inhibitors can enhance TACE efficacy by inhibiting Cezanne-activated EMT, and is therefore a promising combination to prevent recurrence in HCC patients. This study, however, is limited by its retrospective nature. More clinical investigations are needed before mTOR inhibitors can truly benefit more.

\section{Conclusions}

Adjuvant anthracycline-based TACE treatment after curative surgery can reduce the recurrence rate in HCC patients. However, in patients with high expression of Cezanne, the efficacy of TACE may be undermined by EMT inducement. We discovered that Cezanne modulates EMT by activating the AKT/mTOR signaling pathway and provided evidence for the rationale of combining mTOR inhibitor with TACE to prevent recurrence in HCC patients(Fig. 6).

\section{Abbreviations}

Transcatheter arterial chemoembolization (TACE), adjuvant TACE (ad-TACE), epithelium mesenchymal transition (EMT), hepatocellular carcinoma (HCC), overexpressing Cezanne (OE-Cezanne), The Cancer Genome Atlas (TCGA), Barcelona-Clinic Liver Cancer (BCLC), Overall survival (OS), Disease-free survival (DFS), a-fetoprotein (AFP), Tissue microarray (TMA), quantitative real-time PCR (RT-qPCR), optical density (OD), Human Protein Atlas (HPA), hazard ratio (HR), Gene Expression Profiling Interactive Analysis (GEPIA), Hierarchical cluster analysis (HCA), Propensity score matching (PSM)

\section{Declarations}

\section{Ethics approval and consent to participate}

The study participants (or their parents or guardians) provided written informed consent. The study protocol was approved by the research institute's committee on human research. All animal experiments conformed to internationally accepted standards and were approved by the appropriate institutional review body.

\section{Consent for publication}


Not applicable

\section{Availability of data and material}

Cezanne Expression and Gene Expression Profiling Interactive Analysis (GEPIA) profiling plotting and correlation analysis based on the RNA-Seq expression data from The Cancer Genome Atlas (TCGA) (https://portal.gdc.cancer.gov/), the Human Protein Atlas (HPA) (http://www.proteinatlas.org/) and the cBioPortal (https://www.cbioportal.org/). The datasets supporting the conclusions of this article are available in the Research Data Deposit repository(http://www.researchdata.org.cn/).

\section{Competing interests}

All authors have declare that they have no conflicts of interest.

\section{Funding}

This study was supported by the National Natural Science Foundation of China (No. 81871985, 82071101 and 82002068); Natural Science Foundation of Guangdong Province (No. 2021A1515010949, 2018A0303130098 and 2021A1515011142); Science and Technology Special Fund of Guangdong Province (No. 200114165897946); Medical Scientific Research Foundation of Guangdong Province (No. A2020099); Science and Technology Planning Project of Shantou (No. 200624095260243).

\section{Author contributions}

$R G, X Z$, and $A K$ designed the study; $X Z, J W, J M, L L, Y L, S L, A K$ performed the experiments and collected the data; $X Z, J M, L L, Y L, S L, A K$ and $R G$ analyzed and interpreted the data; $S T$ and RG prepared the final draft; and all authors were involved in the initial drafting, review, and approval of the manuscript and the decision to submit it for publication.

\section{Acknowledgements}

The authors would like to thank Prof. J.P. Yun and Dr. M.Y. Cai, Department of Pathology, Sun Yat-sen University Cancer Center for dissecting the tissue samples and providing them for the study. We would also like to thank Editage (www.editage.com) for English language editing.

\section{References}

1. European Association for the Study of the Liver. Electronic address eee, European Association for the Study of the L. EASL Clinical Practice Guidelines: Management of hepatocellular carcinoma. $J$ Hepatol 2018, 69(1): 182-236.

2. Villanueva A. Hepatocellular Carcinoma. N Engl J Med 2019, 380(15): 1450-1462. 
3. Vogel A, Cervantes A, Chau I, Daniele B, Llovet JM, Meyer T, et al. Hepatocellular carcinoma: ESMO Clinical Practice Guidelines for diagnosis, treatment and follow-up. Ann Oncol 2018, 29(Suppl 4): iv238iv255.

4. Wei W, Jian PE, Li SH, Guo ZX, Zhang YF, Ling YH, et al. Adjuvant transcatheter arterial chemoembolization after curative resection for hepatocellular carcinoma patients with solitary tumor and microvascular invasion: a randomized clinical trial of efficacy and safety. Cancer Commun (Lond) 2018, 38(1): 61.

5. Guiu B, Jouve JL, Schmitt A, Minello A, Bonnetain F, Cassinotto C, et al. Intra-arterial idarubicin_lipiodol without embolisation in hepatocellular carcinoma: The LIDA-B phase I trial. $J$ Hepatol 2018, 68(6): 1163-1171.

6. Merle P, Blanc J-F, Phelip J-M, Pelletier G, Bronowicki J-P, Touchefeu Y, et al. Doxorubicin-loaded nanoparticles for patients with advanced hepatocellular carcinoma after sorafenib treatment failure (RELIVE): a phase 3 randomised controlled trial. The Lancet Gastroenterology \& Hepatology 2019, 4(6): 454-465.

7. Shi M, Lu LG, Fang WQ, Guo RP, Chen MS, Li Y, et al. Roles played by chemolipiodolization and embolization in chemoembolization for hepatocellular carcinoma: single-blind, randomized trial. J Natl Cancer Inst 2013, 105(1): 59-68.

8. Minotti G, Menna P, Salvatorelli E, Cairo G, Gianni L. Anthracyclines: molecular advances and pharmacologic developments in antitumor activity and cardiotoxicity. Pharmacol Rev 2004, 56(2): 185229.

9. Seoane JA, Kirkland JG, Caswell-Jin JL, Crabtree GR, Curtis C. Chromatin regulators mediate anthracycline sensitivity in breast cancer. Nat Med 2019, 25(11): 1721-1727.

10. Song C GZ, Ding Y, Tan BH, Desai D, Gowda K, Amin S, et al. IKAROS and CK2 regulate expression of BCL-XL and chemosensitivity in high-risk B-cell acute lymphoblastic leukemia. Blood 2020, 136(13): 1520-1534.

11. D'Amico L, Menzel U, Prummer M, Muller P, Buchi M, Kashyap A, et al. A novel anti-HER2 anthracycline-based antibody-drug conjugate induces adaptive anti-tumor immunity and potentiates PD-1 blockade in breast cancer. $J$ Immunother Cancer 2019, 7(1): 16.

12. Xu B, Sun T, Zhang Q, Zhang P, Yuan Z, Jiang Z, et al. Efficacy of utidelone plus capecitabine versus capecitabine for heavily pretreated, anthracycline- and taxane-refractory metastatic breast cancer: final analysis of overall survival in a phase III randomised controlled trial. Ann Oncol 2021, 32(2): 218-228.

13. Wang JH, Zhong XP, Zhang YF, Wu XL, Li SH, Jian PE, et al. Cezanne predicts progression and adjuvant TACE response in hepatocellular carcinoma. Cell death \& disease 2017, 8(9): e3043. 
14. Huang W, Hennrick K, Drew S. A colorful future of quantitative pathology: validation of Vectra technology using chromogenic multiplexed immunohistochemistry and prostate tissue microarrays. Hum Pathol 2013, 44(1): 29-38.

15. Pastar I, Liang L, Sawaya A, Wikramanayake T, Glinos G, Drakulich S, et al. Preclinical models for wound-healing studies. Skin Tissue Models 2018: 31.

16. Franken NA, Rodermond HM, Stap J, Haveman J, van Bree C. Clonogenic assay of cells in vitro. Nat Protoc 2006, 1(5): 2315-2319.

17. Pijuan J, Barcelo C, Moreno DF, Maiques O, Siso P, Marti RM, et al. In vitro Cell Migration, Invasion, and Adhesion Assays: From Cell Imaging to Data Analysis. Front Cell Dev Bio/ 2019, 7: 107.

18. Yoo SH, Kwon JH, Nam SW, Lee JY, Kim YW, Shim DJ, et al. Transarterial Infusion of Epirubicin and Cisplatin Combined With Systemic Infusion of 5-Flurouracil Versus Sorafenib for Hepatocellular Carcinoma With Refractoriness of Transarterial Chemoembolization Using Doxorubicin. Cancer Control 2020, 27(2): 1073274820935843.

19. Ikeda $M$, Kudo $M$, Aikata $H$, Nagamatsu $H$, Ishii $H$, Yokosuka O, et al. Transarterial chemoembolization with miriplatin vs. epirubicin for unresectable hepatocellular carcinoma: a phase III randomized trial. J Gastroenterol 2018, 53(2): 281-290.

20. Lee SW, Lee HL, Han NI, Kwon JH, Nam SW, Jang JW, et al. Transarterial infusion of epirubicin and cisplatin combined with systemic infusion of 5-fluorouracil versus transarterial chemoembolization using doxorubicin for unresectable hepatocellular carcinoma with portal vein tumor thrombosis: a retrospective analysis. Ther Adv Med Oncol 2017, 9(10): 615-626.

21. Matter MS, Decaens T, Andersen JB, Thorgeirsson SS. Targeting the mTOR pathway in hepatocellular carcinoma: current state and future trends. J Hepatol 2014, 60(4): 855-865.

22. Villanueva A, Chiang DY, Newell P, Peix J, Thung S, Alsinet C, et al. Pivotal role of mTOR signaling in hepatocellular carcinoma. Gastroenterology 2008, 135(6): 1972-1983, 1983 e1971-1911.

23. Kenerson HL, Yeh MM, Kazami M, Jiang X, Riehle KJ, Mclntyre RL, et al. Akt and mTORC1 have different roles during liver tumorigenesis in mice. Gastroenterology 2013, 144(5): 1055-1065.

24. Benjamin D, Colombi M, Moroni C, Hall MN. Rapamycin passes the torch: a new generation of mTOR inhibitors. Nat Rev Drug Discov 2011, 10(11): 868-880.

25. Neef M, Ledermann M, Saegesser H, Schneider V, Reichen J. Low-dose oral rapamycin treatment reduces fibrogenesis, improves liver function, and prolongs survival in rats with established liver cirrhosis. J Hepatol 2006, 45(6): 786-796. 
26. Zhang ZJ, Zheng ZJ, Shi R, Su Q, Jiang Q, Kip KE. Metformin for liver cancer prevention in patients with type 2 diabetes: a systematic review and meta-analysis. J Clin Endocrinol Metab 2012, 97(7): 23472353.

27. Wang B, Jie Z, Joo D, Ordureau A, Liu P, Gan W, et al. TRAF2 and OTUD7B govern a ubiquitindependent switch that regulates mTORC2 signalling. Nature 2017, 545(7654):365-369.

28. Bremm A, Moniz S, Mader J, Rocha S, Komander D. Cezanne (OTUD7B) regulates HIF-1alpha homeostasis in a proteasome-independent manner. EMBO Rep 2014, 15(12):1268-1277.

29. Luong le A, Fragiadaki M, Smith J, Boyle J, Lutz J, Dean JL, et al. Cezanne regulates inflammatory responses to hypoxia in endothelial cells by targeting TRAF6 for deubiquitination. Circ Res 2013, 112(12): 1583-1591.

30. Lin DD, Shen Y, Qiao S, Liu WW, Zheng L, Wang YN, et al. Upregulation of OTUD7B (Cezanne) Promotes Tumor Progression via AKT/VEGF Pathway in Lung Squamous Carcinoma and Adenocarcinoma. Front Oncol 2019, 9: 862.

31. Enesa K, Zakkar M, Chaudhury H, Luong le A, Rawlinson L, Mason JC, et al. NF-kappaB suppression by the deubiquitinating enzyme Cezanne: a novel negative feedback loop in pro-inflammatory signaling. $J$ Biol Chem 2008, 283(11): 7036-7045.

32. Wang JH, Wei W, Guo ZX, Shi M, Guo RP. Decreased Cezanne expression is associated with the progression and poor prognosis in hepatocellular carcinoma. J Trans/ Med 2015, 13: 41.

33. Dongre A, Weinberg RA. New insights into the mechanisms of epithelial-mesenchymal transition and implications for cancer. Nat Rev Mol Cell Biol 2019, 20(2): 69-84.

34. Singh A, Settleman J. EMT, cancer stem cells and drug resistance: an emerging axis of evil in the war on cancer. Oncogene 2010, 29(34): 4741-4751.

35. Zheng X, Carstens JL, Kim J, Scheible M, Kaye J, Sugimoto H, et al. Epithelial-to-mesenchymal transition is dispensable for metastasis but induces chemoresistance in pancreatic cancer. Nature 2015, 527(7579): 525-530.

36. Nieto MA, Huang RY, Jackson RA, Thiery JP. Emt: 2016. Cell 2016, 166(1): 21-45.

37. Llovet JM, De Baere T, Kulik L, Haber PK, Greten TF, Meyer T, et al. Locoregional therapies in the era of molecular and immune treatments for hepatocellular carcinoma. Nat Rev Gastroenterol Hepatol 2021.

38. Kudo M, Ueshima K, lkeda M, Torimura T, Tanabe N, Aikata H, et al. Randomised, multicentre prospective trial of transarterial chemoembolisation (TACE) plus sorafenib as compared with TACE alone in patients with hepatocellular carcinoma: TACTICS trial. Gut 2020, 69(8):1492-1501. 
39. Park JW, Kim YJ, Kim DY, Bae SH, Paik SW, Lee YJ, et al. Sorafenib with or without concurrent transarterial chemoembolization in patients with advanced hepatocellular carcinoma: The phase III STAH trial. J Hepatol 2019, 70(4): 684-691.

40. Meyer T, Fox R, Ma YT, Ross PJ, James MW, Sturgess R, et al. Sorafenib in combination with transarterial chemoembolisation in patients with unresectable hepatocellular carcinoma (TACE 2): a randomised placebo-controlled, double-blind, phase 3 trial. The Lancet Gastroenterology \& Hepatology 2017, 2(8): 565-575.

\section{Figures}


Fig. 1
A
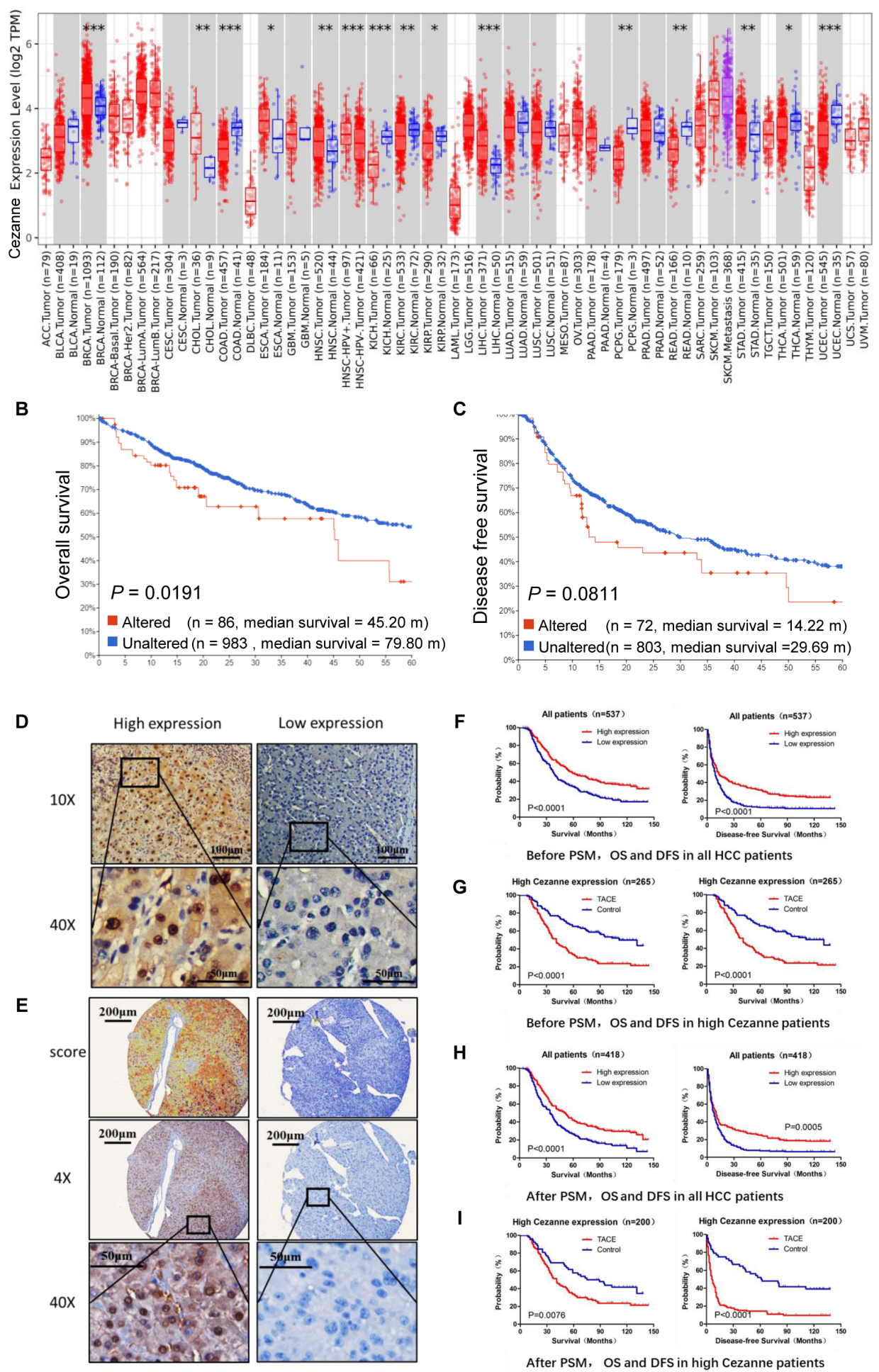

\section{Figure 1}

Aberrant Cezanne expression predicts worse outcome and better response to adjuvant TACE therapy in HCC patients. Cezanne expression in normal and cancer tissues assessed by the Human Protein Atlas (HPA) (A). The relationship between the altered level of Cezanne and overall survival analyzed by cBioPortal based on the RNA-Seq expression data of 1064 samples from The Cancer Genome Atlas (TCGA) (B). The relationship between the altered level of Cezanne and disease-free survival analyzed by 
cBioPortal based on the RNA-Seq expression data from TCGA (C). Immunohistochemistry staining Cezanne expression in HCC samples. The left panel represents high Cezanne expression in tumor tissue. The right panel represents low Cezanne expression in HCC. The full line and dotted line scale bar represent $50 \mu \mathrm{m}$ and $10 \mu \mathrm{m}$, respectively (D). Automated image acquisition was captured by the Vectra slide scanner. A scoring system generated by InForm 1.2 software package was used to segment tissue and subcellular compartments (E). Kaplan-Meier (KM) survival estimates and log-rank tests were used to analyze the prognostic significance of Cezanne expression in all patients (F). KM survival estimates to analyze the prognostic significance of adjuvant-TACE treatment in Cezanne high-expression patients (G). KM survival estimates to analyze the prognostic significance of Cezanne expression after propensity score matching analysis $(\mathrm{H})$. KM survival estimates to analyze the prognostic significance of adjuvantTACE treatment in Cezanne high-expression patients after propensity score matching analysis (I). 
Fig. 2

A

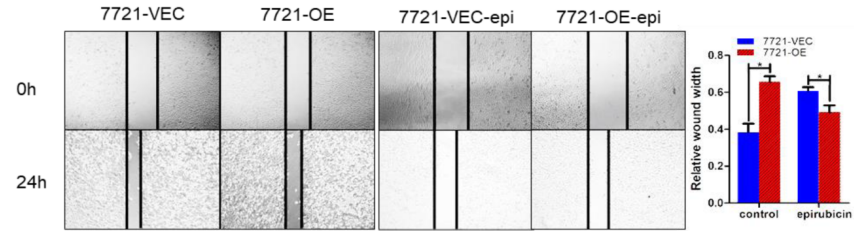

B

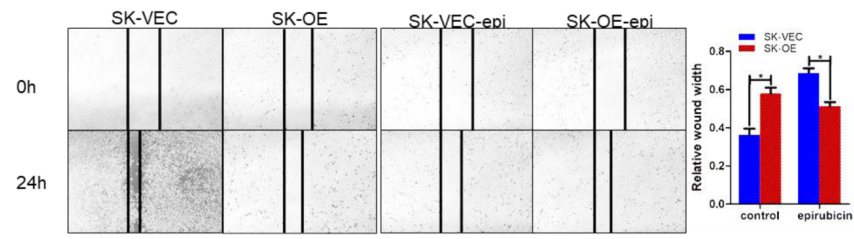

C

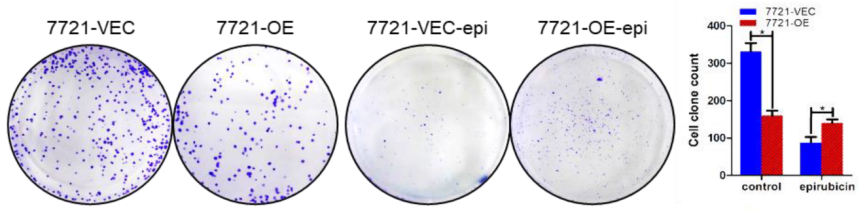

D

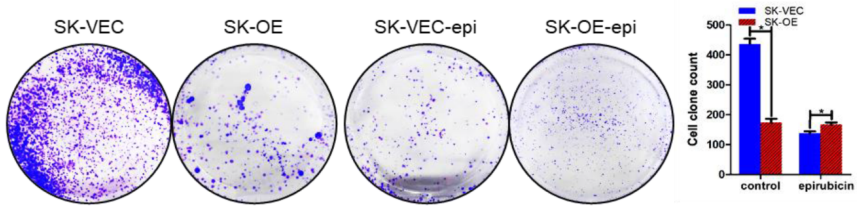

E


I

$\mathrm{H}^{5}{ }^{-} \rightarrow$ SK-VEC
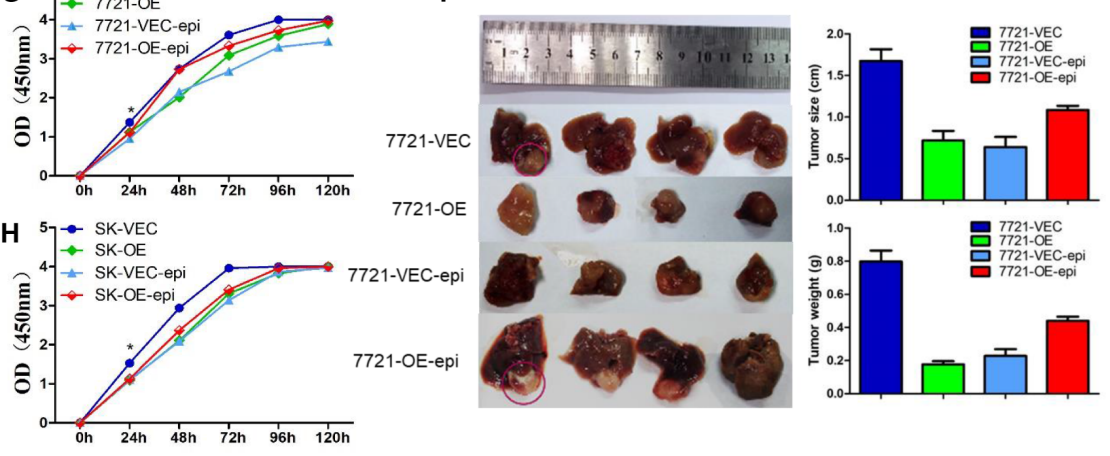

\section{Figure 2}

Cezanne affects epirubicin efficacy in both in vivo and in vitro experiments. Wound healing assay shows that Cezanne inhibits cell invasion and decline epirubicin efficacy in HCC cell lines (A, B). Cloning assay suggesting after overexpression of Cezanne inhibit HCC cell lines cloning and decline epirubicin efficacy (C, D). Cezanne upregulated in HCC cell lines inhibited cell migration and invasion and decline epirubicin efficacy (E, F). CCK-8 assay suggesting after overexpression of Cezanne inhibit HCC cell lines 
proliferation and decline epirubicin efficacy $(G, H)$. In situ tumorigenesis model verifying that overexpression of Cezanne inhibit HCC cell lines proliferation and decline epirubicin efficacy (I).

Fig. 3
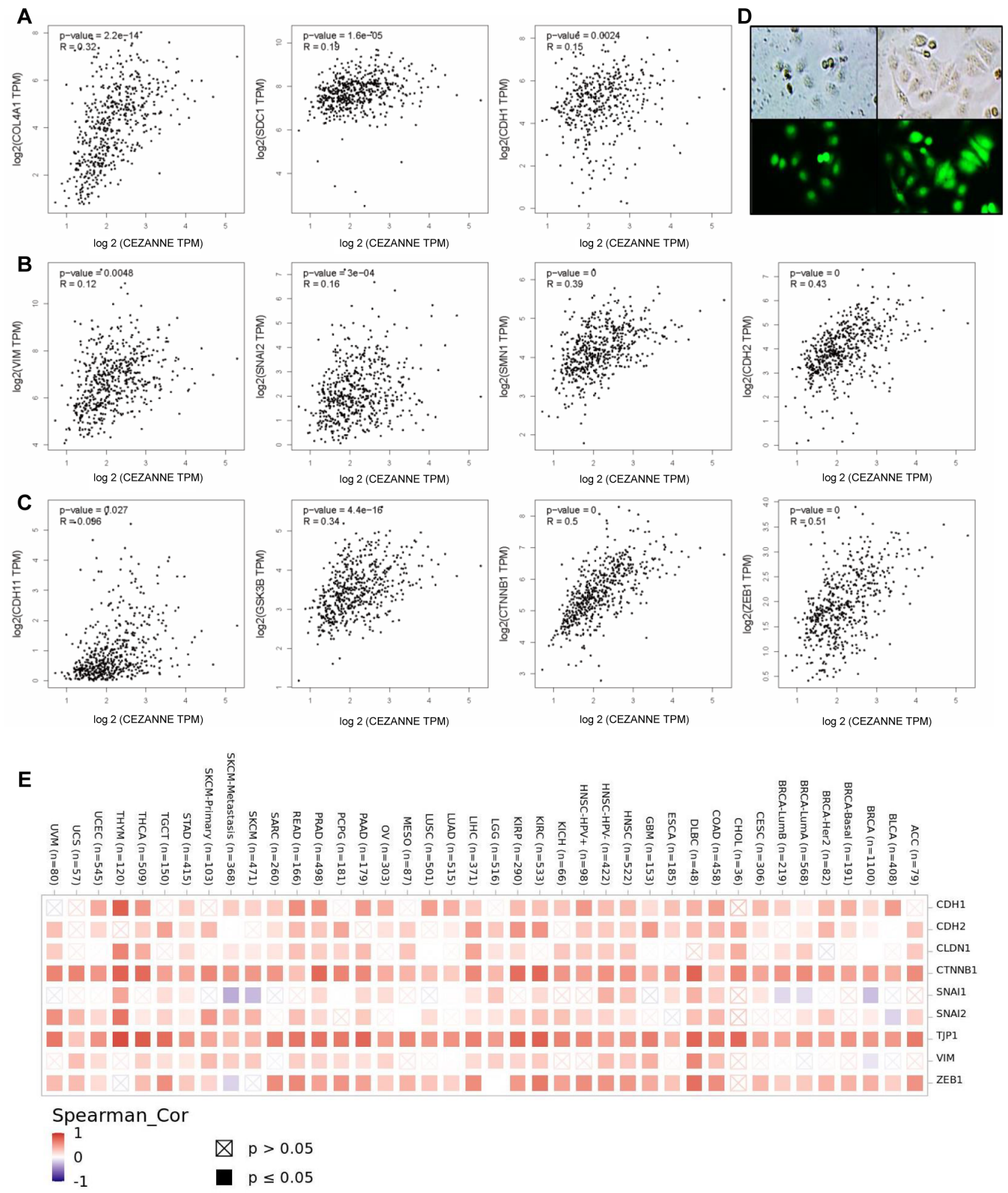

\section{Figure 3}

High expression of Cezanne transforms cell morphology and is correlated to the activation of EMT related genes. Gene Expression Profiling Interactive Analysis (GEPIA) profiling plotting and correlation analysis based on the RNA-Seq expression data from The Cancer Genome Atlas (TCGA) showed positive 
correlation with epithelial markers including COL4A1, SDC1 and CDH1 (A). GEPIA profiling plotting and correlation analysis based on the RNA-Seq expression data from TCGA showed correlation with mesenchymal markers including vimentin, snail, slug and $\mathrm{CDH} 2$ (B). GEPIA profiling plotting and correlation analysis based on the RNA-Seq expression data from TCGA showed correlation with regulating markers of EMT such as CDH11, GSK3 3, CTNNB1 and ZEB1 correlated with Cezanne (C). Morphological changes in Cezanne over expression cell lines under a microscope. Cells were elongated and displayed spindle-like morphologies compared to vector cells (D). Cezanne's correlation with EMT was analyzed in multiple cancer types (E). 
Fig. 4

A

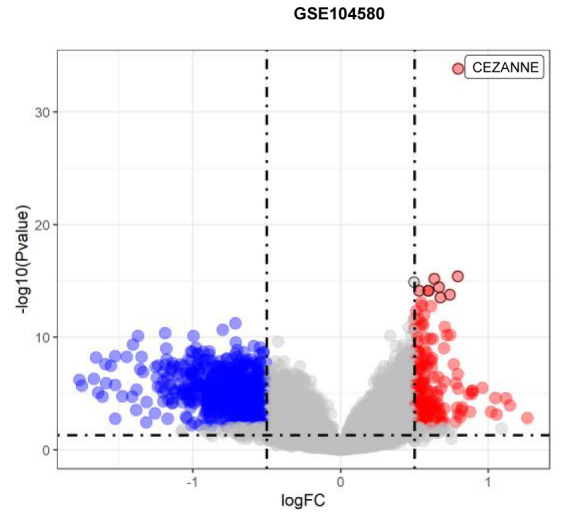

B

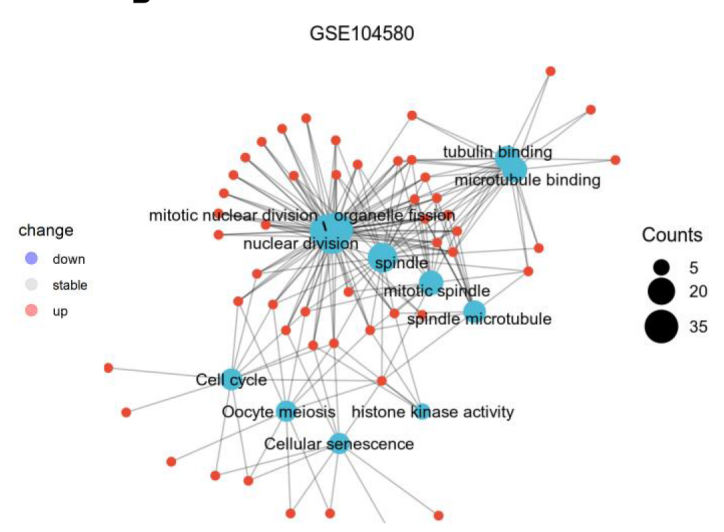

C

GSE104580


\section{Figure 4}

Cezanne activates EMT by regulating PI3K/AKT/mTOR signaling pathway. Bioinformatic analysis showed. Expression profiling array of GSE104580 showed genes with significant difference in the high expression of Cezanne were visualized as a volcano plot (A). Gene set pathway enrichment analysis indicated that up-regulation of Cezanne was highly correlated with mitotic cell cycle progression (B). HCA of the significantly different genes revealed 2 main clusters of co-regulated genes on the mTOR pathway 
(C). Western blotting showed that AKT1 and mTOR had a higher expression after overexpression of Cezanne in HCC cell lines compared to the control group. This difference was even more significant after treating HCC cell lines with epirubicin (D). This result was confirmed in the RNA level (E). Representative images of IHC staining of mice xenografts of overexpression of Cezanne and control cells and correlated AKT1 and mTOR expression. The scale bar represents $100 \mu \mathrm{m}(\mathrm{F})$.

Fig. 5

A

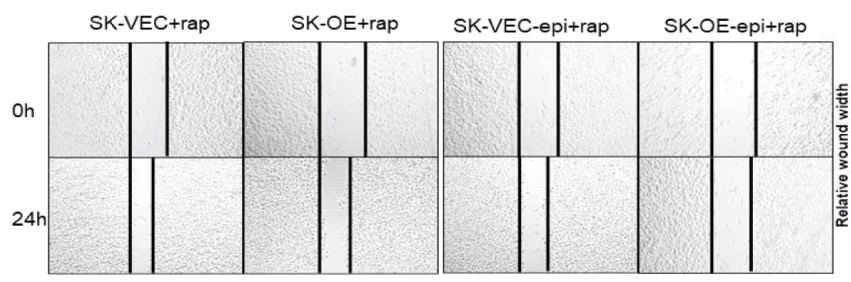

B

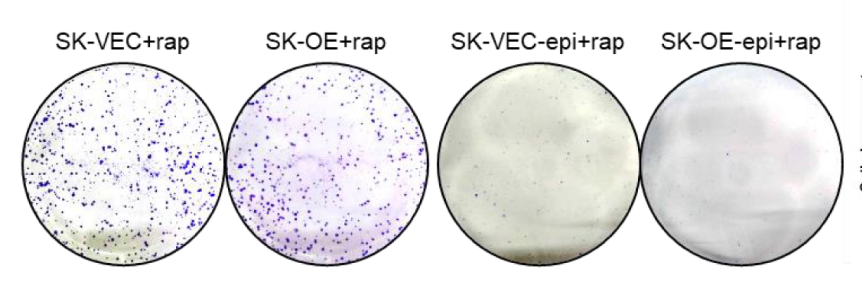

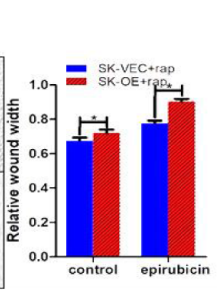

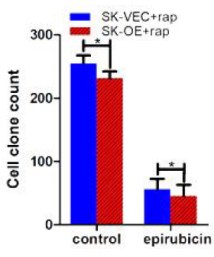

C

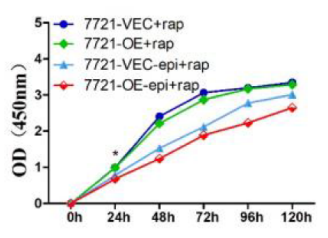

D

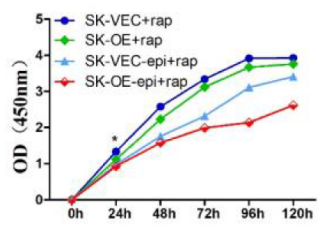

E



$\mathbf{F}$

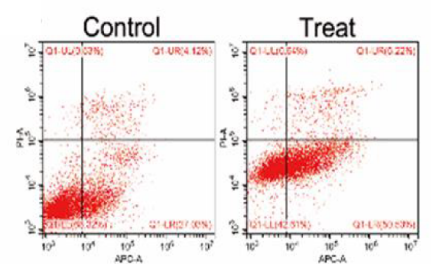

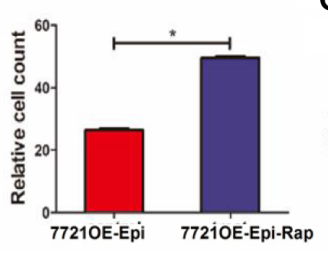

G

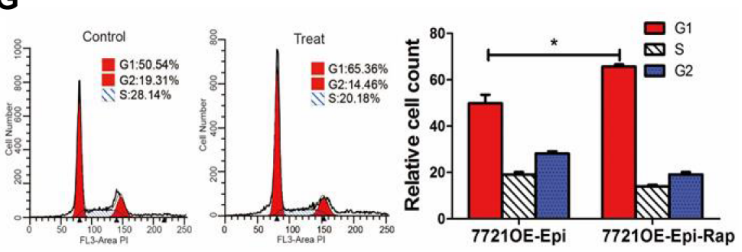

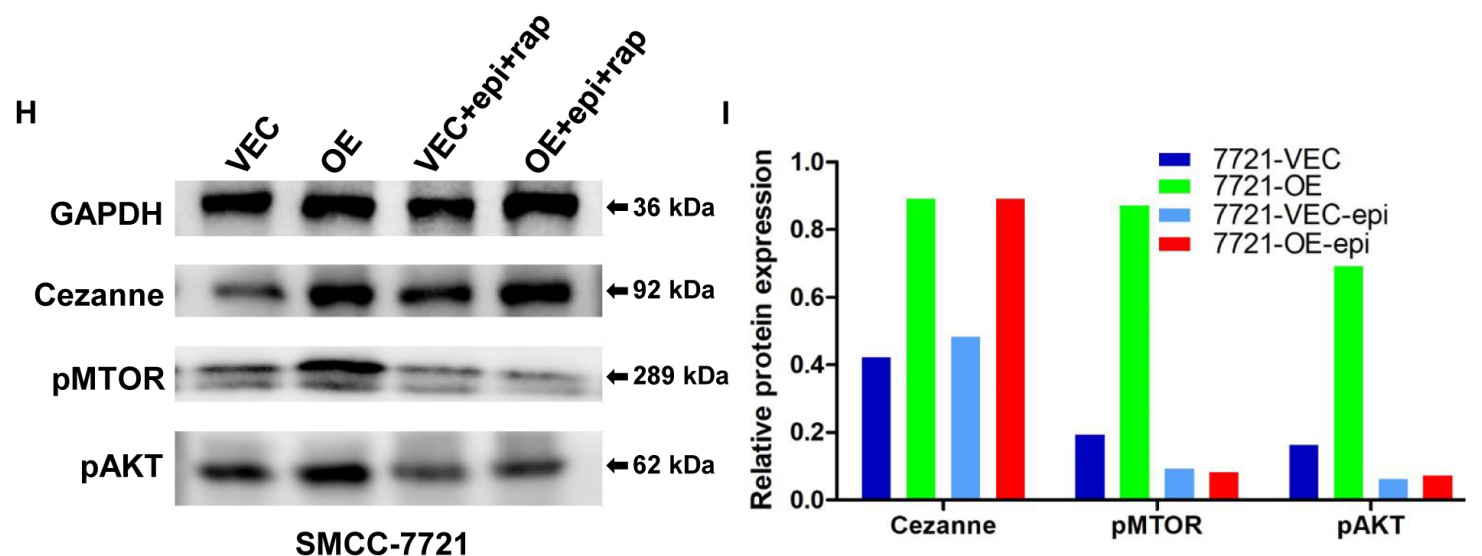

Figure 5 
mTOR inhibitor Rapamycin can reverse the resisting effect of Cezanne on HCC cell lines. Wound healing assay shows that Rapamycin inhibits cell invasion and restore epirubicin efficacy in Cezanne overexpressing $\mathrm{HCC}$ cell lines (A). Cloning assay suggesting after Rapamycin inhibits cell cloning and restore epirubicin efficacy in Cezanne overexpressing HCC cell lines (B). CCK-8 assay suggesting after Rapamycin inhibits cell proliferation and restore epirubicin efficacy in Cezanne overexpressing HCC cell lines (C, D). Rapamycin inhibits cell migration and invasion and restore epirubicin efficacy in Cezanne overexpressing HCC cell lines (E). Apoptosis assay showed that in the Cezanne overexpression cell lines treated with epirubicin, apoptosis was increased with Rapamycin treatment (F). Cell cycle analyzation assay indicated that Cezanne overexpression cell lines treated with Rapamycin were significantly arrested in $\mathrm{G} 1$ phase (G). The expression of Cezanne, mTOR and AKT1 in Cezanne overexpression cell lines treated with epirubicin by Western blot $(\mathrm{H})$. The expression of mTOR and AKT1 decreased with Rapamycin, while the expression of Cezanne remained unchanged. This result was confirmed by mRNA expression detected with RT qPCR (I).

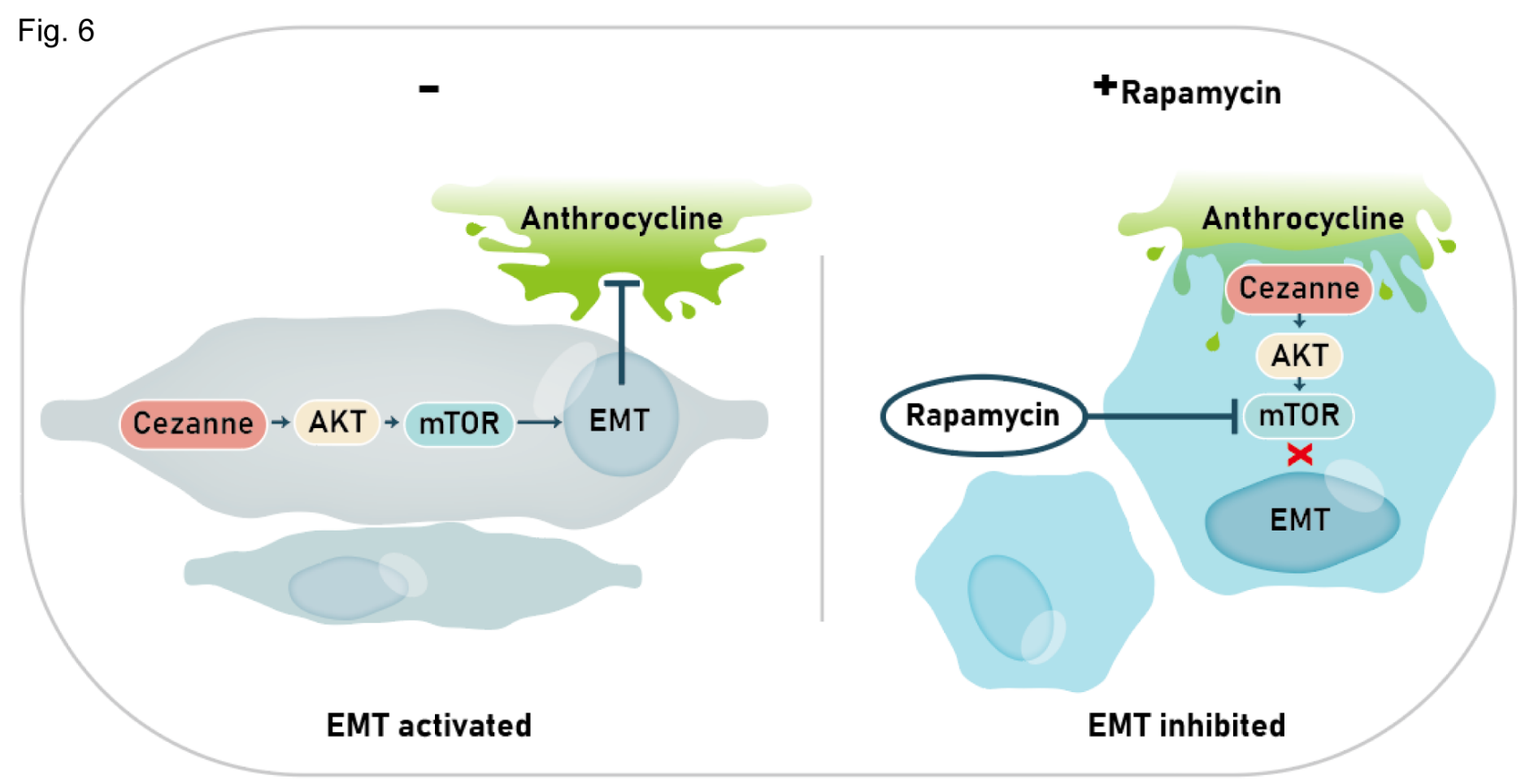

Figure 6

Major findings in graphic form. Cezanne activates epithelium mesenchymal transition (EMT) to anthracycline resistance through the AKT/mTOR signaling pathway in hepatocellular carcinoma (HCC). Rapamycin (mTOR inhibitor) can reverse EMT inducement and the anthracycline resistance of Cezanne on HCC cell lines.

\section{Supplementary Files}


This is a list of supplementary files associated with this preprint. Click to download.

- supplementsTable.docx

- supplementsfigure.pdf 